\title{
Gene Expression in Macrophage-rich Human Atherosclerotic Lesions 15-Lipoxygenase and Acetyl Low Density Lipoprotein Receptor Messenger RNA Colocalize with Oxidation Specific Lipid-Protein Adducts
}

\author{
Seppo Ylä-Herttuala," Michael E. Rosenfeld," Sampath Parthasarathy, E Elliott Sigal," \\ Terttu Särkioja," Joseph L. Witztum, ${ }^{*}$ and Daniel Steinberg* \\ *Division of Endocrinology and Metabolism, Department of Medicine, University of California, San Diego, California 92093; \\ ${ }^{\ddagger}$ Cardiovascular Research Institute, University of California, San Francisco, California 94143; and \\ ${ }^{\$}$ Department of Forensic Medicine, University of Oulu, Finland
}

\begin{abstract}
Oxidatively modified low density lipoprotein (LDL) exhibits several potentially atherogenic properties, and inhibition of LDL oxidation in rabbits decreases the rate of the development of atherosclerotic lesions. In vitro studies have suggested that cellular lipoxygenases may be involved in LDL oxidation, and we have shown previously that 15-lipoxygenase and oxidized LDL are present in rabbit atherosclerotic lesions.

We now report that epitopes of oxidized LDL are also found in macrophage-rich areas of human fatty streaks as well as in more advanced human atherosclerotic lesions. Using in situ hybridization and immunostaining techniques, we also report that 15-lipoxygenase mRNA and protein colocalize to the same macrophage-rich areas. Moreover, these same lesions express abundant mRNA for the acetyl LDL receptor but no detectable mRNA for the LDL receptor. We suggest that atherogenesis in human arteries may be linked to macrophage-induced oxidative modification of LDL mediated by 15-lipoxygenase, leading to subsequent enhanced macrophage uptake, partly by way of the acetyl LDL receptor. (J. Clin. Invest. 1991. 87:1146-1152.) Key words: in situ hybridization • immunocytochemistry • oxidized LDL • LDL-receptor • scavenger receptor
\end{abstract}

\section{Introduction}

The sequence of events leading to clinically significant atherosclerotic lesions in man remains to be established. There is an emerging consensus that the first grossly identifiable lesion is the fatty streak but there may be exceptions. Indeed, there may be not one but rather several alternative pathogenetic sequences. The hallmark of the fatty streak lesion is fat-laden foam cells (1). Most of these represent monocyte/macrophages (2-4), but a significant number also are derived from smooth muscle cells (1). A consensus is also growing around the proposition that LDL must first undergo one or another modification in its structure and biological properties before it can be taken up rapidly enough by the monocyte/macrophage to gen-

Address correspondence to Daniel Steinberg, Department of Medicine 0613-D, University of California San Diego, 9500 Gilman Drive, La Jolla, CA 92093-0613.

Received for publication 7 September 1990 and in revised form 2 November 1990.

J. Clin. Invest.

(c) The American Society for Clinical Investigation, Inc.

0021-9738/91/04/1146/07 \$2.00

Volume 87, April 1991, 1146-1152 erate a foam cell (5-8). This hypothesis, while supported by a growing body of in vitro and in vivo evidence, is based largely on studies of cultured cells and on studies in experimental animals. It has not been tested in humans.

One of the modifications of LDL that has been implicated in foam cell formation is oxidative modification $(8,9)$. Recently, several lines of evidence have been developed that strongly suggest that oxidative modification of LDL occurs in vivo: (a) immunostaining of rabbit arteries has shown that oxidized LDL and/or oxidation-specific lipid-protein adducts are present in atherosclerotic lesions (10-14); (b) LDL gently extracted from both human and rabbit lesions has the chemical and biological properties of oxidized LDL (15-17); (c) human and rabbit serum contain autoantibodies against epitopes of oxidized LDL $(11,18)$; and $(d)$ antioxidant therapy decreases the progression of atherosclerotic lesions in the Watanabe heritable hyperlipidemic (WHHL) ${ }^{1}$ rabbit $(19,20)$.

Various cell types can oxidatively modify $\mathrm{LDL}$ in vitro $(8$, $9,21,22)$. This process is initiated by lipid peroxidation and is accompanied by breakdown of the LDL apoprotein B, fragmentation of polyunsaturated fatty acids and the conjugation of various reactive aldehydes such as malondialdehyde (MDA) and 4-hydroxynonenal (4-HNE) to apoprotein B lysine residues $(8,23,24)$. As a result of these changes, novel epitopes are generated on the oxidized LDL that are recognized by macrophage receptors (8).

Studies in this laboratory have led to the proposition that the oxidative modification may be effected by the action of lipoxygenases (LO) in macrophages and in endothelial cells $(14,25-27)$ (and possibly other cell types as well). In vitro studies suggest that cellular LO may play an important role in this process: LDL treated with soybean $\mathrm{LO}$ and phospholipase $\mathrm{A}_{2}$ closely resembles oxidized LDL (25) and several LO inhibitors can block cell-induced oxidation of $\operatorname{LDL}(26,27)$. We have shown recently that 15-LO mRNA and protein are expressed in macrophage-rich areas of WHHL rabbit atherosclerotic lesions and that the expression colocalizes with the epitopes characteristic for oxidized LDL (14). Atherosclerotic lesions of rabbit and human aorta $(28,29)$ also show higher levels of $15-\mathrm{LO}$ enzymatic activity than corresponding normal arteries.

The pathway by which the oxidized LDL is taken up in monocyte/macrophages involves in part the acetyl LDL receptor, which was first described by Goldstein et al. $(5,30)$ and was

1. Abbreviations used in this paper: 4-HNE, 4-hydroxynonenal; LO, lipoxygenase; MDA, malondialdehyde; WHHL, Watanabe heritable hyperlipidemic. 
recently cloned by Kodama and co-workers (31). Additional receptors may be involved but these remain poorly defined (32, 33). Macrophage foam cells isolated from fatty streaks have been shown to take up acetylated LDL more rapidly than native LDL, compatible with the presence of the acetyl LDL receptor (34-36), but more direct evidence for its expression in situ is needed.

The purpose of the present study was to localize epitopes of oxidized LDL in fatty streaks and more advanced atherosclerotic lesions obtained from human aortas, to determine if 15LO mRNA and protein colocalized to the same sites, and to determine what types of lipoprotein receptor mRNAs are expressed in human lesions.

\section{Methods}

Tissue samples. Human aortic samples were obtained from two organ donors for renal transplants (ages 28 and $33 \mathrm{yr}$ ) and from three medicolegal autopsies (ages 25, 37 and $64 \mathrm{yr}$ ), 4-6 h postmortem. The possibility of postmortem changes in the autopsy specimens cannot be ruled out but major artifacts are unlikely because the results in the postmortem samples were similar to those in the samples obtained directly from organ donors or perfusion-fixed animals (see Fig. 3, $A-D$, and references $11,13,14)$. Tissue samples were immediately transferred to formal-sucrose at $4^{\circ} \mathrm{C}(4 \%$ paraformaldehyde, $5 \%$ sucrose, $1 \mathrm{mM}$ EDTA, $50 \mu \mathrm{M}$ butylated hydroxytoluene, $\mathrm{pH}$ 7.4). After overnight fixation, samples were paraffin-embedded and serial sections $(10 \mu \mathrm{m})$ were used for in situ hybridization and immunocytochemical studies (14). As a positive control for the expression of LDL receptor mRNA, perfusionfixed adrenal glands from New Zealand White rabbits were embedded in paraffin and handled identically. All human and animal studies were approved by the Human Subjects Committee and the Animal Subjects Committee of the University of California, San Diego.

In situ hybridization. The following probes were subcloned into plasmid vectors (37) and used for in situ hybridization: A 2.7-kb Eco RI fragment (nucleotides 1-2716) of human 15-LO cDNA (38) was subcloned into pBluescript KS II (Stratagene Inc., San Diego, CA); a 2.2kb Eco RI-Bc11 fragment (nucleotides - 34 to +2185 ) of human 5-LO cDNA (39) was subcloned into pTZ19R (Pharmacia Fine Chemicals, Piscataway, NJ); a 1.6-kb Eco RI fragment (nucleotides 1-1580) of bovine type I acetyl LDL receptor CDNA (31) was subcloned into pBluescript SK II; a 0.7-kb Hind III-Eco RI fragment (nucleotides - 13-718) and a 0.4-kb Sph I-Xho I fragment (nucleotides 2107-2544) of human LDL receptor cDNA (40) were subcloned into pGEM4Z (Promega Biotec, Madison, WI); and a 0.5-kb Bam HI-Pst I fragment (nucleotides 1-547) of human retinoic acid receptor cDNA (41) was subcloned into pGEM4Z.

The synthesis of antisense and sense riboprobes was carried out using Sp6, T7, or T3 RNA polymerases with ${ }^{35} \mathrm{~S}-\mathrm{UTP}(1,200 \mathrm{Ci} / \mathrm{mmol}$, New England Nuclear, Boston, MA) $(14,42)$. Reagents used for riboprobe synthesis were from Promega Biotec except that T3 RNA polymerase was from Stratagene, Inc. After the probe synthesis, cDNA templates were digested with RNAse-free DNAse (Promega Biotec), unincorporated isotope was removed using spin columns (Nu-Clean R50, International Biotech Inc., New Haven, CT), samples were extracted with phenol/chloroform and chloroform, and precipitated with ethanol (14). The specific activity of the probes varied from 250 to 300 $\mathrm{Ci} / \mathrm{mmol}$. Before use, probe sizes were reduced by alkaline hydrolysis (43) to an average length of 250 nucleotides. Probe sizes were confirmed by polyacrylamide gel electrophoresis, and their specificity was tested on Northern blot analysis (37). The nucleotide sequence of the human acetyl LDL receptor(s) is not yet known, but on Northern blots the bovine acetyl LDL receptor probe recognized mRNA isolated from stimulated human THP-1 cells ( 31 ) and the probe was considered suitable for in situ hybridization studies with human tissue. ${ }^{2}$ To control the

2. See note added in proof at end of this article. specificity of the in situ hybridizations two control hybridizations were done routinely in addition to the nonhybridizing sense probe controls (see below): pretreatment of the sections with RNAse A abolished the signal; and human retinoic acid receptor probe used as an irrelevant probe did not hybridize to the sections.

In situ hybridizations were done as described previously (14): tissue sections were deparaffinized, digested with proteinase $\mathrm{K}(1 \mu \mathrm{g} / \mathrm{ml}, 10$ min at $37^{\circ} \mathrm{C}$; Boehringer-Mannheim Biochemicals, Indianapolis, IN), and acetylated $(0.25 \%$ acetic anhydride in $0.1 \mathrm{M}$ triethanolamine, 10 $\left.\min 20^{\circ} \mathrm{C}\right)(14)$. Slides were washed twice in $2 \times \operatorname{SSC}(1 \times \mathrm{SSC}=150$ $\mathrm{mM} \mathrm{NaCl}, 15 \mathrm{mM} \mathrm{Na}$-citrate, $\mathrm{pH} 7.0$ ), dehydrated, and dried in vacuo. Each hybridization experiment was done from a set of serial sections using an antisense probe and a corresponding nonhybridizing sense probe. $45 \mu$ l of hybridization solution (see below) containing 3-6 $\times 10^{6}$ $\mathrm{cpm} / \mathrm{ml}$ of each probe was added to the slides and they were hybridized at $50-52^{\circ} \mathrm{C}$ for $14 \mathrm{~h}(14)$. After the hybridization the slides were washed three times (15 min each) in $4 \times$ SSC and digested with RNAse A (20 $\mu \mathrm{g} / \mathrm{ml}$; Sigma Chemical Co., St. Louis, MO) for $30 \mathrm{~min}$ at $37^{\circ} \mathrm{C}$. The slides were then washed at room temperature with $2 \times \mathrm{SSC}, 1 \times \mathrm{SSC}$, and $0.5 \times \mathrm{SSC}$ for $15 \mathrm{~min}$ (two times each). The final wash was 0.1 $\times \mathrm{SSC}$ at $60^{\circ} \mathrm{C}$ (with $\mathrm{LO}$ probes), or $55^{\circ} \mathrm{C}$ (other probes) for $60 \mathrm{~min}$. After the RNAse A step each washing solution contained $1 \mathrm{mM}$ dithiothreitol and $1 \mathrm{mM}$ EDTA. Slides were then dried, dipped in photographic emulsion (NTB-2, Eastman-Kodak Co., Rochester, NY), and developed after 3-10 wk exposure time. After the development the slides were counterstained with hematoxylin-eosin. In situ hybridization solution contains $50 \%$ formamide (Fluka), $2 \times$ SSC, $20 \mathrm{mM}$ Tris, pH 7.4, $1 \times$ Denhardt's solution, 1 mM EDTA, $10 \%$ dextran sulphate (Pharmacia Fine Chemicals), $1 \mathrm{mM}$ dithiothreitol, and $0.5 \mathrm{mg} / \mathrm{ml}$ yeast tRNA (Boehringer-Mannheim Biochemicals). $1 \times$ Denhardt's solution contains $0.02 \%$ Ficoll, $0.02 \%$ polyvinylpyrrolidone, and $0.02 \%$ BSA (all from Sigma Chemical Co.).

Immunocytochemistry. Serial paraffin-embedded sections were used for immunostaining using previously described antibodies: mouse monoclonal antibodies against human macrophages (HAM-56) (44) and smooth muscle cells (HHF-35) (45), guinea pig polyclonal antisera against MDA- and 4-HNE-modified LDL (MAL-2, HNE-6, respectively) (11, 18); and Sepharose G-purified rabbit (46) and goat antisera against human recombinant 15-LO (14). Avidin-biotin-horseradish peroxidase system was used for the immunostaining (Vector Laboratories Inc., Burlingame, CA). After immunocytochemistry the slides were counterstained with methyl green.

\section{Results}

Human atherosclerotic lesions contained both monocyte-derived macrophages and smooth muscle cells as identified by monoclonal antibodies. An example of a macrophage-rich fatty streak is seen in Fig. 1: macrophages occupied the upper part of the lesion (Fig. $1 A$ ), whereas smooth muscle cells were mostly located in the deeper portions of the intima (Fig. $1 \mathrm{~B}$ ). The macrophage-rich areas and some smooth muscle cells stained positively with polyclonal antisera against MDA-LDL (Fig. $1 C$ ) and 4HNE-LDL (Fig. $1 D$ ) indicating the presence of oxidized LDL and/or oxidation-specific lipid-protein adducts. The same areas also contained 15 -LO protein (Fig. $1 E$ ). At higher magnification 15-LO (Fig. $1 F$ ) and MAL-2 (Fig. $1 G$ ) immunostainings showed a similar intracellular distribution, as previously reported for WHHL rabbit lesions $(11,13,14)$. In lesions some intracellular 15-LO and MAL-2 immunostaining was also located in cells fulfilling the morphological criteria for smooth muscle cells. In contrast, the normal smooth muscle cells in the media were uniformly negative.

In situ hybridizations with antisense riboprobes showed 15 LO mRNA (Fig. $1, I$ and $K$ ) and acetyl LDL receptor mRNA expression (Fig. $1 J$ and $L$ ) in the same macrophage-rich areas 

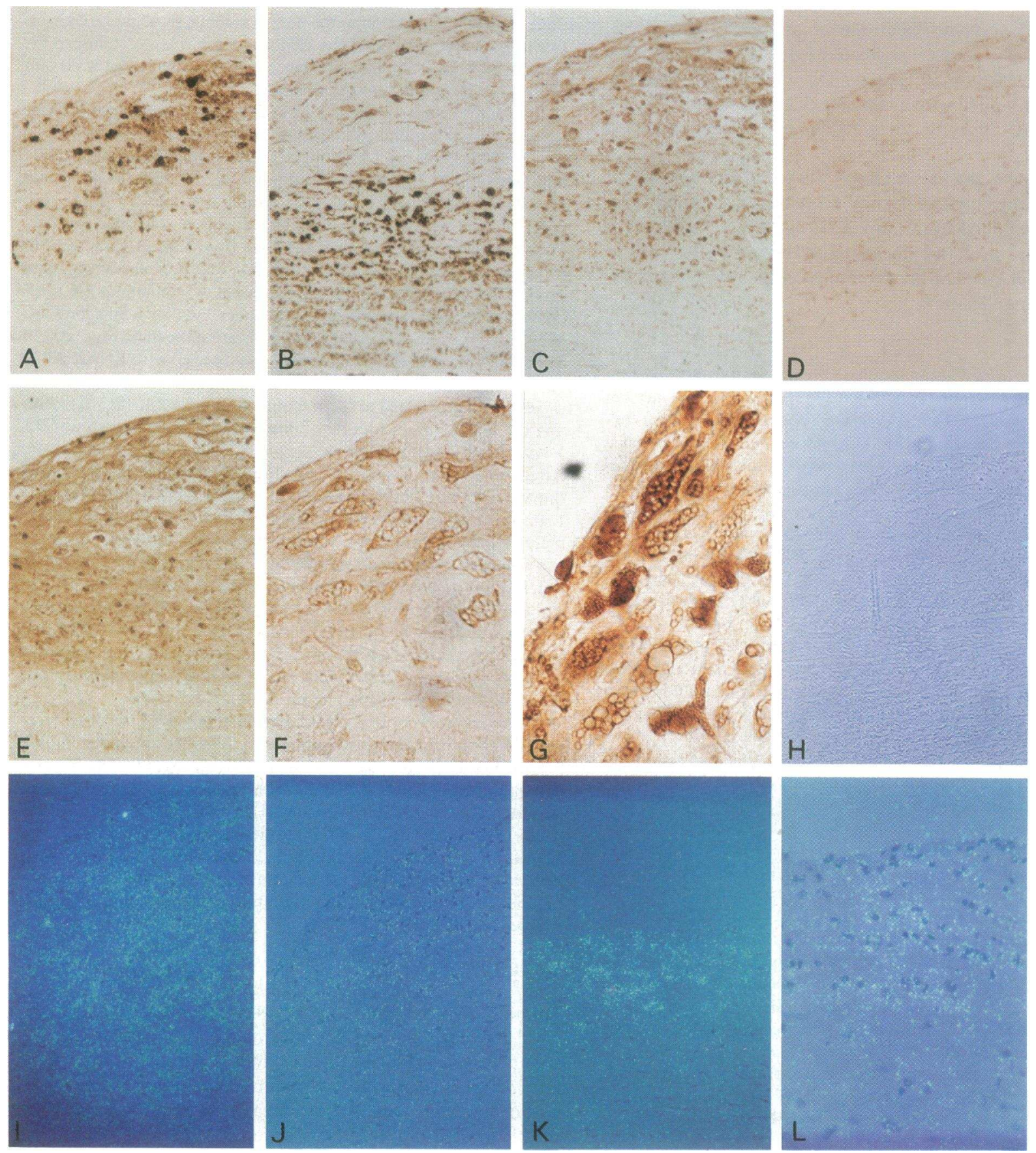

Figure 1. 15-LO and acetyl LDL receptor mRNA colocalize with oxidized LDL and macrophages in a human fatty streak lesion (abdominal aorta of a 37-yr-old female, postmortem time $5 \mathrm{~h}$ ). Immunostaining of serial sections (avidin-biotin-horseradish peroxidase system): $(A)$ antibody specific for human macrophages (HAM-56; 1:1,000 dilution); $(B)$ antibody specific for human smooth muscle cells (HHF-35; dilution 1:500); (C) antibody against MDA-modified LDL (MAL-2; 1:500 dilution); $(D)$ antibody against 4HNE-modified LDL (HNE-6; dilution 1:1,000); $(E)$ antibody against recombinant human 15-LO protein (goat antiserum, 1:500 dilution); $(F)$ higher magnification of an area comparable to $\mathrm{E}$ stained with antibody against recombinant human 15-LO protein (goat antiserum, 1:500 dilution); $(G)$ higher magnification of an area comparable to $C$ stained with antibody against MDA-modified LDL (MAL-2; 1:500 dilution); $(H)$ nonimmune control for the immunostaining; $(I, J)$ In situ hybridizations of serial sections using ${ }^{35} \mathrm{~S}$-labeled riboprobes: $(I)$ human 15 -LO antisense probe; and $(J)$ bovine acetyl LDL receptor antisense probe; $(K, L)$ in situ hybridization of another macrophage-rich fatty streak comparable to the lesion shown in $A-J ;(K)$ human 15 -LO antisense probe; and $(L)$ bovine acetyl LDL receptor antisense probe. Hybridization of the serial sections in $I-L$ with the corresponding sense probes were negative (data not shown). Exposure time in $I-L$ was 8 wk. Methyl green counter stain in $A-H$. Hematoxylin-eosin counter stain in $I-L$. Photographs in $A-H$ were taken using bright field illumination; photographs in $I-L$ were taken using polarized light epiluminescence. Magnification 125, except in $L(250)$ and in $F$ and $G(625)$. 
that stained positively for $15-\mathrm{LO}$ protein and oxidized $\mathrm{EDL}$. No hybridization was seen with the corresponding sense probes or with the 5-LO antisense probe (data not shown). Another example of the expression of acetyl LDL receptor mRNA in a macrophage-rich fatty streak is seen in Fig. $2 A$. No expression of LDL receptor mRNA was seen in the same areas (Fig. $2 C$ ). However, as a positive control, a clear in situ hybridization signal with the LDL receptor probe was detected in a section of rabbit adrenal cortex (47) (Fig. 2 D).

Macrophages found in areas of diffuse intimal thickening already expressed 15-LO mRNA and protein and stained positively for oxidation-specific lipid-protein adducts (Fig. 3). In advanced atherosclerotic lesions the majority of the cells were identified as smooth muscle cells (Fig. $4 A$ ) and only relatively few macrophages were found in these lesions (Fig. $4 \mathrm{~B}$ ). However, as in the fatty streaks, the macrophages in these later lesions expressed 15-LO mRNA (Fig. $4 C$ ) and acetyl LDL receptor mRNA (Fig. $4 \mathrm{D}$ ). In general, it should be noted that 15-LO mRNA expression was present in all areas occupied by macrophages, whereas expression of the acetyl LDL receptor mRNA was variable, some macrophage-like cells being positive and others negative, suggesting some type of regulation and/or cell subtype specificity in the expression of the macrophage acetyl LDL receptor. As with the other lesions studied (Figs. 1-3), these lesions also contained oxidation-specific epitopes, although there was more diffuse staining involving the matrix (data not shown) as shown previously in advanced rabbit lesions (13).

\section{Discussion}

These studies show for the first time that human atherosclerotic lesions react with several antibodies directed against epitopes found on oxidized LDL but not on native LDL. These epitopes were predominantly found in macrophage-rich area's of both early fatty streaks and more advanced lesions, but immunostaining was also frequently seen associated with intimal smooth muscle cells, some of them laden with lipid droplets. Most of the immunostaining appeared to be intracellular, suggesting that these epitopes accumulated as a result of continuing uptake of oxidized LDL. Oxidized LDL appears to resist lysosomal degradation and to accumulate in cultured macrophages (32). However, we have previously shown that LDL eluted from human lesions contains the oxidation-specific epitopes (15) showing that some oxidized LDL is extracellular. It is also possible that further oxidation occurs within the cells after uptake of modified LDL (13). Sections of aorta that did not contain frank atherosclerotic lesions were negative for epitopes of oxidized LDL, but in areas of diffuse intimal thickening there were often scattered macrophages that reacted positively. As in the case of rabbit lesions, the adventitia at lesion sites also contained oxidation-specific eptiopes $(11,13,14)$.

The present results also establish that acetyl LDL receptor mRNA is expressed in macrophage-rich areas of human lesions. These findings, together with the previously published evidence of acetyl LDL receptor function in macrophages isolated from atherosclerotic lesions (34-36), suggest that this receptor could be actively involved in the uptake of oxidized LDL in human lesions. In contrast, no mRNA for the native LDL receptor could be detected, further indicating that this receptor is not importantly involved in lipid accumulation in human lesions. Finally, we find that both mRNA for LO and also LO protein colocalize in macrophage-rich lesions along with epitopes characteristic of oxidized LDL. The comparative in situ hybridization signal for expression of LO in human lesions is less than that previously observed in WHHL rabbits (14), possibly because the human lesions contain relatively more smooth muscle cells and fewer macrophages.

Several lines of evidence make it likely that the LO detected is 15-LO rather than 5-LO or 12-LO: (a) the 15-LO antisense probe gave a strong signal whereas the 5-LO antisense probe, used in the same way, gave no detectable signal; $(b)$ the $15-\mathrm{LO}$ signal was detected using stringent conditions (up to $60^{\circ} \mathrm{C}$ ) that should have limited cross-reactivity with other messages; $(c)$ the antiserum used to detect LO protein in these sections was raised against pure recombinant human 15-LO protein and does not cross-react with human platelet 12-LO or leukocyte 5-LO; and $(d)$ 15-LO metabolites are preferentially generated in both rabbit and human atherosclerotic lesions $(28,29)$. However, we cannot rule out the possibility that the probes used in this study, in addition to detecting 15-LO mRNA, also detect some 12-LO mRNA because some isoforms of 12-LO are known to be highly homologous to $15-\operatorname{LO}(48,49)$. The consequences of the action of either of these enzymes on LDL, however, would be expected to be similar, i.e., the propagation reactions and the further modification of the LDL particle is unlikely to be strongly dependent upon the position at which the hydroperoxide is initially introduced into the unsaturated fatty acid.

The human lesions studied here were deliberately selected because they contained a relatively large number of foam cells, identified as monocyte-derived by use of a monoclonal antibody specific for monocyte/macrophages. These lesions represent a human counterpart of the macrophage-rich lesions seen in nonhuman primates (50) and rabbits (51) and probably represent a very early stage in human atherosclerosis (52). It was not possible to quantify the extent to which lesions of the kind selected contribute to the overall aortic atherosclerosis in the patients studied and so the results should not be taken to be necessarily representative. Nevertheless, the generation of human lesions of this kind, expressing the genes studied (15-LO and acetyl LDL receptor), is compatible with the possibility that the oxidative modification pathway for fatty streak formation may be operative in early human atherosclerosis.

These human lesions differ in some ways from the lesions previously studied in LDL receptor-deficient rabbits $(11,13$, 14). The density of foam cells was considerably less and there was relatively more connective tissue matrix. In addition, there were more smooth muscle cells containing fat droplets. The rabbit lesions, of course, develop rapidly (over a period of months) in animals with plasma cholesterol levels in the 600$800 \mathrm{mg} / \mathrm{dl}$ range; by contrast, the human lesions develop in response to a much more moderate degree of hypercholesterolemia and over a much longer time interval. Despite these and other species differences, the lesions have a commonality: the macrophage foam cells contain epitopes reactive to antibodies against oxidized LDL in both cases; they show a high level of expression of 15-LO by in situ hybridization; and they are apparently negative for 5-LO. The mRNA for 15-LO colocalized with the immunostaining for epitopes characteristic of oxidized LDL and all appeared to be closely associated with macrophage-derived foam cells. In addition, these studies also provide important additional evidence that macrophages, even in 

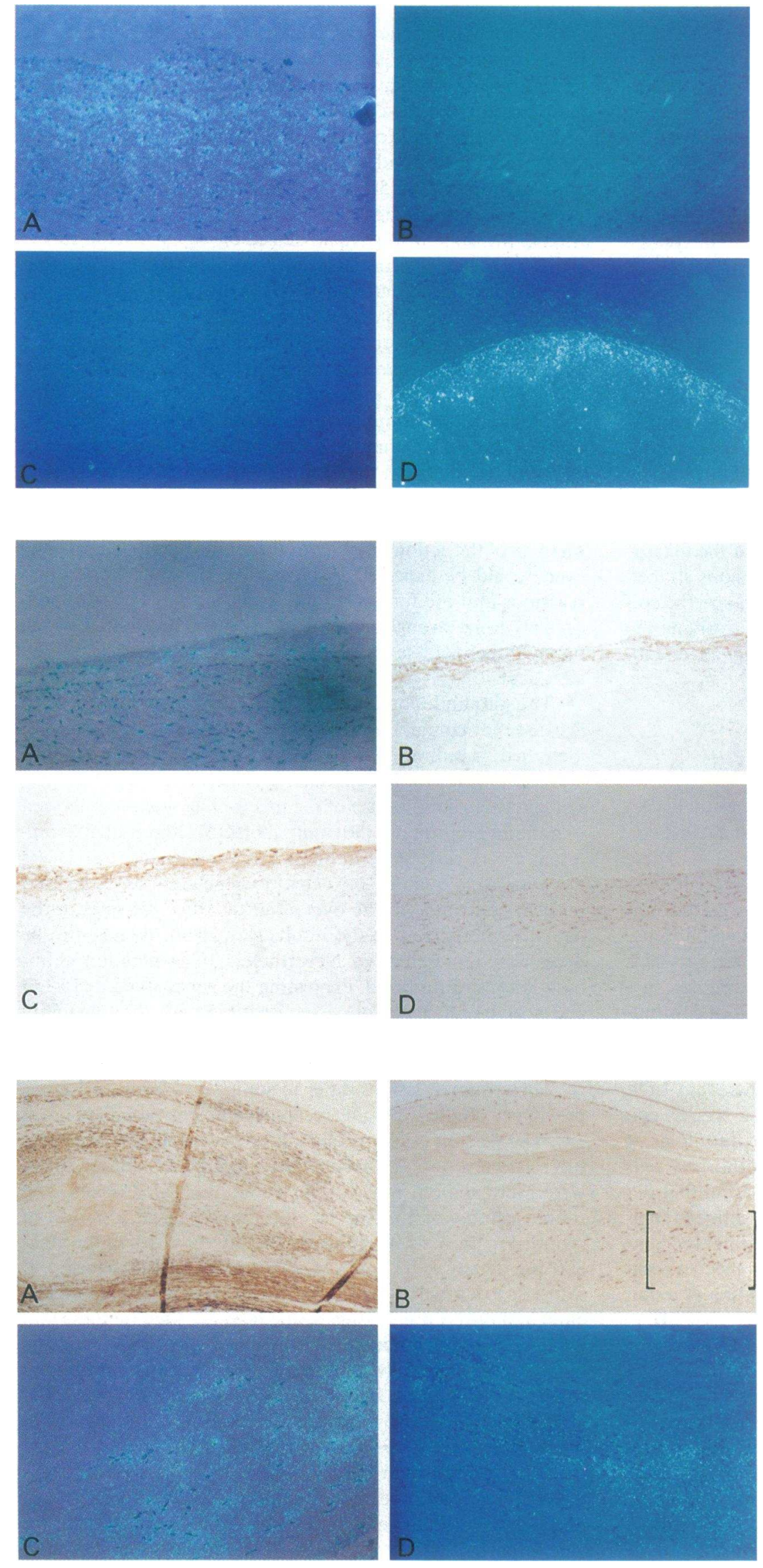

Figure 2. Acetyl LDL receptor mRNA expression and the absence of LDL receptor mRNA expression in a human fatty streak (abdominal aorta, 37-yr-old female, postmortem time $5 \mathrm{~h}$ ). In situ hybridizations of the serial sections with $(A)$ bovine acetyl LDL receptor antisense probe; $(B)$ bovine acetyl LDL receptor nonhybridizing sense probe; $(C)$ human LDL receptor antisense probe; $(D)$ positive control using a section of New Zealand White rabbit adrenal gland and the human $\mathrm{LDL}$ receptor antisense probe. Exposure time $10 \mathrm{wk}$. Hematoxylin-eosin counter stain. Photographs were taken using polarized light epiluminescence. Magnification 125, except in $D(25)$.

Figure 3. 15-LO mRNA and protein expression in macrophages in an area of diffuse intimal thickening (abdominal aorta, 28-yr-old male, renal transplant donor). $(A)$ In situ hybridization with human 15-LO antisense probe, exposure time $8 \mathrm{wk}$; hybridization with 15 -LO sense probe was negative (data not shown). Immunostaining of serial sections with $(B)$ antibody against recombinant human 15-LO protein (goat antiserum, 1:500 dilution); $(C)$ antibody against human macrophages (HAM-56; 1:1,000 dilution); and $(D)$ antibody against MDA-LDL (MAL-2, 1:500 dilution). Nonimmune controls for immunostaining were negative (data not shown). Hematoxylin-eosin counter stain in $A$, methyl green counter stain in $B-D$. Photograph in $A$ was taken using polarized light epiluminescence; photographs in $B-D$ were taken using bright field illumination. Magnification 62.5, except $D(100)$.

Figure 4. 15-LO and acetyl LDL receptor mRNA expression in an advanced atherosclerotic lesion (abdominal aorta, 64-yr-old male, postmortem time $6 \mathrm{~h}$ ). Immunostainings of the serial sections with $(A)$ antibody against human smooth muscle cells (HHF-35, dilution 1:500); $(B)$ antibody against human macrophages (HAM-56; 1:1,000 dilution). Nonimmune controls for the immunostaining were negative (data not shown). In situ hybridization of serial sections (bracketed macrophage-rich area shown in $B$ ) with $(C)$ human 15-LO antisense probe; $(D)$ bovine acetyl LDL receptor antisense probe. Exposure time in $C$ and $D$ was 10 wk. Control hybridizations with the respective sense probes were negative (data not shown). Methyl green counter stain in $A$ and $B$, hematoxylin-eosin counter stain in $C$ and $D$. Photographs in $A$ and $B$ were taken using bright field illumination, photographs in $C$ and $D$ were taken using polarized light epiluminescence. Magnification in $A$ and $B 25$, in $C$ and $D 125$. 
the advanced human lesion, continue to actively express the acetyl LDL receptor and contain oxidation-specific epitopes. Furthermore, because human peripheral monocytes, the precursors of macrophages, do not express 15-LO (53, Sigal, E., unpublished data) and because other tissue macrophages (e.g., alveolar macrophages) do not express 15-LO (53, and Sigal, E., unpublished data), the findings in the atherosclerotic aorta imply a lesion-specific induction of macrophage $15-\mathrm{LO}$. What factors in the microenvironment elicit this induction remains to be determined. The results are compatible with, but do not prove, the hypothesis that oxidation of LDL is effected by macrophages expressing a high level of 15-LO activity, as appears to be the case in rabbit lesions (14). Once initiation of the peroxidation of LDL lipids has begun, the oxidized LDL may be atherogenic by multiple mechanisms $(8,54-57)$ and may directly contribute to macrophage lipid accumulation because of enhanced uptake mediated by the acetyl LDL receptor.

The use of in situ hybridization promises to be a valuable way to study the pathogenesis of atherosclerosis using human tissues. This technique allows ascertainment at a microlevel of gene expression in specific cell types at each stage during lesion development. While this approach is still a "static" approach, it at least allows us to ask whether hypotheses generated from experimental studies are compatible with the pathogenesis of the human disease. These studies represent a beginning, however, suggesting that the oxidative modification hypothesis may be relevant to the human disease and that inhibition of LDL oxidation and/or macrophage 15-LO activity might decrease the rate of the development of atherosclerotic lesions.

\section{Acknowledgments}

We thank the Tissue Transplantation Center at the University of California, San Diego, for collecting some of the arterial specimens; Drs. David W. Russell, Joseph L. Goldstein, and Michael S. Brown (University of Texas Health Science Center at Dallas) for human LDL receptor cDNA; Dr. Bengt Samuelsson (Karolinska Institutet, Sweden) for human 5-LO cDNA; Dr. Monty Krieger (Massachusetts Institute of Technology, Cambridge) for bovine scavenger receptor (type I) cDNA; Dr. Christopher K. Glass (University of California, San Diego) for human retinoic acid receptor cDNA; Dr. Allen M. Gown (University of Washington, Seattle) for the HAM-56 and HHF-35 antisera; Dr. David Sloane for supplying purified rabbit 15-LO; Ms. Ella Highland for assistance in preparing the 15-LO antibodies; and Ms. Paula Sicurello for technical assistance.

This study was supported by grants from NHLBI 14197 (SCOR on Arteriosclerosis), the Emil Aaltonen Foundation (Finland) (SYH) and the Helsinki Heart Study Foundation (Finland) (SYH), a Grant-in-Aid (No. 89-176) from the California affiliate of the American Heart Association (MER), and National Institutes of Health PPG HL-24136 (ES) and National Institutes of Health Clinical Investigator Award HL02047 (ES).

Note added in proof: The sequence for the type I human acetyl LDL receptor cDNA was recently published by Matsumoto et al. (1990. Proc. Natl. Acad. Sci. USA. 87:9133-9137). It shows 79\% identify with that of the bovine cDNA used in the present studies. The authors also observed immunostaining for the acetyl LDL receptor in human atherosclerotic lesions.

\section{References}

1. Ross, R. 1986. The pathogenesis of atherosclerosis: an update. N. Engl. J. Med. 314:488-500.
2. Fowler, S., H. Shio, and N. J. Haley. 1979. Characterization of lipid-laden aortic cells from cholesterol-fed rabbits. IV. Investigation of macrophage-like properties of aortic cell populations. Lab. Invest. 41:372-378.

3. Gerrity, R. G., H. K. Naito, M. Richardson, and C. J. Schwartz. 1979. Dietary induced atherogenesis in swine. Am. J. Pathol. 95:775-792.

4. Schaffner, T., K. Taylor, E. J. Bartucci, K. Fischer-Dzoga, J. H. Beeson, S Glagov, and R. W. Wissler. 1980. Arterial foam cells with distinctive immunomorphologic and histochemical features of macrophages. Am. J. Pathol. 100:5780.

5. Brown, M. S., and J. L. Goldstein. 1983. Lipoprotein metabolism in the macrophage: implications for cholesterol deposition in atherosclerosis. Annu. Rev. Biochem. 52:223-261.

6. Mahley, R. W., T. L. Innerarity, K. H. Weisgraber, and S. Y. Oh. 1979. Altered metabolism (in vivo and in vitro) of plasma lipoproteins after selective chemical modification of lysine residues of the apoproteins. J. Clin. Invest. 64:743-750.

7. Fogelman, A. M., I. Schechter, J. Seager, M. Hokum, J. S. Child, and P. E. Edwards. 1980. Malondialdehyde alteration of low density lipoprotein leads to cholesteryl ester accumulation in human monocyte-macrophages. Proc. Natl. Acad. Sci. USA. 77:2214-2218.

8. Steinberg, D., S. Parthasarathy, T. E. Carew, J. C. Khoo, and J. L. Witztum 1989. Beyond cholesterol. Modifications of low-density lipoprotein that increase its atherogenicity. N. Engl. J. Med. 320:915-924.

9. Henriksen, T., E. M. Mahoney, and D. Steinberg. 1981. Enhanced macrophage degradation of low density lipoprotein previously incubated with cultured endothelial cells: recognition by receptor for acetylated low density lipoproteins. Proc. Natl. Acad. Sci. USA. 78:6499-6503.

10. Haberland, M. E., D. Fong, and L. Cheng. 1988. Malondialdehyde-altered protein occurs in atheroma of Watanabe heritable hyperlipidemic rabbits. Science (Wash. DC). 241:215-218.

11. Palinski, W., M. E. Rosenfeld, S. Ylä-Herttuala, G. C. Gurtner, S. A Socher, S. W. Butler, S. Parthasarathy, T. E. Carew, D. Steinberg, and J. L. Witztum. 1989. Low density lipoprotein undergoes oxidative modification in vivo. Proc. Natl. Acad. Sci. USA. 86:1372-1376.

12. Boyd, H. C., A. M. Gown, G. Wolfbauer, and A. Chait. 1989. Direct evidence for a protein recognized by a monoclonal antibody against oxidatively modified LDL in atherosclerotic lesions from a Watanabe heritable hyperlipidemic rabbit. Am. J. Pathol. 135:815-825.

13. Rosenfeld, M. E., W. Palinski, S. Ylä-Herttuala, S. Butler, and J. L. Witztum. 1990. Distribution of oxidation specific lipid-protein adducts and apolipoprotein B in atherosclerotic lesions of varying severity from WHHL rabbits. Arteriosclerosis. 10:336-349.

14. Ylä-Herttuala, S., M. E. Rosenfeld, S. Parthasarathy, C. K. Glass, E. Sigal, J. L. Witztum, and D. Steinberg. 1990. Colocalization of 15-lipoxygenase mRNA and protein with epitopes of oxidized low density lipoprotein in macrophage-rich areas of atherosclerotic lesions. Proc. Natl. Acad. Sci. USA. 87:6959-6963.

15. Ylä-Herttuala, S., W. Palinski, M. E. Rosenfeld, S. Parthasarathy, T. E. Carew, S. Butler, J. L. Witztum, and D. Steinberg. 1989. Evidence for the presence of oxidatively modified low density lipoprotein in atherosclerotic lesions of rabbit and man. J. Clin. Invest. 84:1086-1095.

16. Ylä-Herttuala, S., O. Jaakkola, C. Ehnholm, M. J. Tikkanen, T. Solakivi, T. Sărkioja, and T. Nikkari. 1988. Characterization of two lipoproteins containing apolipoproteins $B$ and $E$ from lesion-free human aortic intima. J. Lipid Res. 29:563-572.

17. Ylä-Herttuala, S., W. Palinski, M. E. Rosenfeld, D. Steinberg, and J. L. Witztum. 1990. Lipoproteins in normal and atherosclerotic aorta. Eur. Heart J. 11:88-99.

18. Palinski, W., S. Ylä-Herttuala, M. E. Rosenfeld, S. W. Butler, S. A. Socher, S. Parthasarathy, L. K. Curtiss, and J. L. Witztum. 1990. Antisera and monoclonal antibodies specific for epitopes generated during oxidative modification of low density lipoproteins. Arteriosclerosis. 10:325-335.

19. Carew, T. E., D. C. Schwenke, and D. Steinberg. 1987. Antiatherogenic effect of probucol unrelated to its hypocholesterolemic effect: evidence that antioxidants in vivo can selectively inhibit low density lipoprotein degradation in macrophage-rich fatty streaks and slow the progression of atherosclerosis in the Watanabe heritable hyperlipidemic rabbit. Proc. Natl. Acad. Sci. USA. 84:77257729.

20. Kita, T., Y. Nagano, M. Yokode, K. Ishii, N. Kume, A. Ooshima, H. Yoshida, and C. Kawai. 1987. Probucol prevents the progression of atherosclerosis in Watanabe heritable hyperlipidemic rabbit, an animal model for familial hypercholesterolemia. Proc. Natl. Acad. Sci. USA. 84:5928-5931.

21. Heinecke, J. W., H. Rosen, and A. Chait. 1984. Iron and copper promote modification of low density lipoprotein by human arterial smooth muscle cells in culture. J. Clin. Invest. 74:1890-1894.

22. Parthasarathy, S., D. J. Printz, D. Boyd, L. Joy, and D. Steinberg. 1986 Macrophage oxidation of low density lipoprotein generates a modified form recognized by the scavenger receptor. Arteriosclerosis. 6:505-510.

23. Steinbrecher, U. P., S. Parthasarathy, D. S. Leake, J. L. Witztum, and D. Steinberg. 1984. Modification of low density lipoprotein by endothelial cells in- 
volves lipid peroxidation and degradation of low density lipoprotein phospholipids. Proc. Natl. Acad. Sci. USA. 83:3883-3887.

24. Steinbrecher, U. P., J. L. Witztum, S. Parthasarathy, and D. Steinberg. 1987. Decrease in reactive amino groups during oxidation or endothelial cel modification of LDL: correlation with changes in receptor-mediated catabolism. Arteriosclerosis. 7:135-143.

25. Sparrow, C. P., S. Parthasarathy, and D. Steinberg. 1988. Enzymatic modification of low density lipoprotein by purified lipoxygenase plus phospholipase $A_{2}$ mimics cell-mediated oxidative modification. J. Lipid Res. 29:745-753.

26. Parthasarathy, S., E. Wieland, and D. Steinberg. 1989. A role for endothelial cell lipoxygenase in the oxidative modification of low density lipoprotein. Proc. Natl. Acad. Sci. USA. 86:1046-1050.

27. Rankin, S., S. Parthasarathy, and D. Steinberg. 1991. Evidence for a dominant role of lipoxygenase(s) in the oxidation of LDL by mouseperitoneal macrophages. J. Lipid Res. In press.

28. Henriksson, P., M. Hamberg, and U. Diczfalusy. 1985. Formation of 15-HETE as a major hydroxyeicosatetraenoic acid in the atherosclerotic vessel wall. Biochim. Biophys. Acta. 834:272-274.

29. Simon, T. C., A. N. Makheja, and J. M. Bailey. 1989. Formation of 15-hydroxyeicosatetraenoic acid (15-HETE) as the predominant eicosanoid in aortas from Watanabe heritable hyperlipidemic and cholesterol-fed rabbits. Atherosclerosis. 75:31-38.

30. Goldstein, J. L., Y. K. Ho, S. K. Basu, and M. S. Brown. 1979. Binding site on macrophages that mediates uptake and degradation of acetylated low density lipoprotein, producing massive cholesterol deposition. Proc. Natl. Acad Sci. USA. 76:333-337.

31. Kodama, T., M. Freeman, L. Rohrer, J. Zabrecky, P. Matsudaira, and M. Krieger. 1990. Type I macrophage scavenger receptor contains $\alpha$-helical and collagen-like coiled coils. Nature (Lond.). 343:531-535.

32. Sparrow, C. P., S. Parthasarathy, and D. Steinberg. 1989. A macrophage receptor that recognizes oxidized low density lipoprotein but not acetylated low density lipoprotein. J. Biol. Chem. 264:2599-2604.

33. Arai, H., T. Kita, M. Yokode, S. Narumiya, and C. Kawai. 1989. Multiple receptors for modified low density lipoproteins in mouse peritoneal macrophages: different uptake mechanisms for acetylated and oxidized low density lipoproteins. Biochem. Biophys. Res. Commun. 159:1375-1382.

34. Pitas, R. E., T. L. Innerarity, and R. W. Mahley. 1983. Foam cells in explants of atherosclerotic rabbit aortas have receptors for $\beta$-very low density lipoproteins and modified low density lipoproteins. Arteriosclerosis. 3:2-12.

35. Jaakkola, O., S. Ylä-Herttuala, T. Särkioja, and T. Nikkari. 1989. Macrophage foam cells from human aortic fatty streaks take up $\beta$-VLDL and acetylated LDL in primary culture. Atherosclerosis. 79:173-182.

36. Rosenfeld, M. E., J. C. Khoo, E. Miller, S. Parthasarathy, W. Palinski, and J. L. Witztum. 1991. Macrophage-derived foam cells freshly isolated from rabbit atherosclerotic lesions degrade modified lipoproteins, promote oxidation of LDL, and contain oxidation specific lipid-protein adducts. J. Clin. Invest. 87:90-99.

37. Maniatis, T., E. F. Fritsch, and J. Shambrook. 1982. Molecular Cloning: A Laboratory Manual. Cold Spring Harbor Laboratory, Cold Spring Harbor, NY. 38. Sigal, E., C. S. Craik, E. Highland, D. Grunberger, L. L. Costello, R. A. F. Dixon, and J. A. Nadel. 1988. Molecular cloning and primary structure of human 15-lipoxygenase. Biochem. Biophys. Res. Commun. 157:457-464.

39. Matsumoto, T., C. D. Funk, O. Rådmark, J.-O. Höög, J. Jörnvall, and B. Samuelsson. 1988. Molecular cloning and amino acid sequence of human 5-lipoxygenase. Proc. Natl. Acad. Sci. USA. 85:26-30.

40. Yamamoto, T., C. G. Davis, M. S. Brown, W. J. Schneider, M. L. Casey,
J. L. Goldstein, and D. W. Russell. 1984. The human LDL receptor: a cysteinerich protein with multiple Alu sequences in its mRNA. Cell. 39:27-38.

41. Giguere, V., E. S. Ong, P. Segui, and R. M. Evans. 1987. Identification of a receptor for the morphogen retinoic acid. Nature (Lond.). 330:624-629.

42. Melton, D. A., P. A. Krieg, M. R. Rebagliati, T. Maniatis, K. Zinn, and M. R. Green. 1984. Efficient in vitro synthesis of biologically active RNA and RNA hybridization probes from plasmids containing a bacteriophage SP6 promoter. Nucleic Acids Res. 12:7035-7056.

43. Cox, K. H., D. V. DeLeon, L. M. Angerer, and R. C. Angerer. 1984. Detection of mRNAs in sea urchin embryos by in situ hybridization using asymmetric RNA probes. Dev. Biol. 101:485-502.

44. Gown, A. M., T. Tsukuda, and R. Ross. 1986. Human atherosclerosis. II. Immunocytochemical analysis of the cellular composition of human atherosclerotic lesions. Am. J. Pathol. 125:191-207.

45. Tsukada, T., D. Tippens, H. Mar, D. Gordon, R. Ross, and A. M. Gown. 1986. HHF-35: a muscle-actin-specific monoclonal antibody. Am. J. Pathol 126:51-60.

46. Sigal, E., D. Grunberger, E. Highland, C. Gross, R. A. F. Dixon, and C. S. Craik. 1990. Expression of cloned human reticulocyte 15-lipoxygenase and immunological evidence that 15 -lipoxygenases of different cell types are related. $J$. Biol. Chem. 265:5113-5120.

47. Swanson, L. W., D. M. Simmons, S. L. Hofmann, J. L. Goldstein, and M. S. Brown. 1988. Localization of mRNA for low density lipoprotein receptor and a cholesterol synthetic enzyme in rabbit nervous system by in situ hybridization. Proc. Natl. Acad. Sci. USA. 85:9821-9825.

48. Yoshimoto, T., H. Suzuki, S. Yamomoto, T. Takai, C. Yokoyama, and T Tanabe. 1990. Cloning and sequence analysis of the cDNA for arachidonate 12-lipoxygenase of porcine leukocytes. Proc. Natl. Acad. Sci. USA. 87:21422146.

49. Funk, C. D., F. Lucinda, and G. A. Fitzgerald. 1990. Molecular cloning primary structure, and expression of the human platelet/erythroleukemia cell 12-lipoxygenase. Proc. Natl. Acad. Sci. USA. 87:5638-5642.

50. Faggiotto, A., R. Ross, and L. Harker. 1984. Studies of hypercholesterolemia in the nonhuman primate. I. Changes that lead to fatty streak formation. Arteriosclerosis. 4:323-340.

51. Rosenfeld, M. E., T. Tsukada, A. M. Gown, and R. Ross. 1987. Fatty streak initiation in Watanabe heritable hyperlipemic and comparably hypercholesterolemic fat-fed rabbits. Arteriosclerosis. 1:9-23.

52. Stary, H. C. 1989. Evolution and progression of atherosclerotic lesions in coronary arteries of children and young adults. Arteriosclerosis. 9:I-19-I-32

53. Bigby, T. D., and M. J. Holtzman. 1987. Enhanced 5-lipoxygenase activity in lung macrophages compared to monocytes from normal subjects. $J$. Immunol. 138:1546-1550.

54. Quinn, M. T., S. Parthasarathy, L. G. Fong, and D. Steinberg. 1987. Oxidatively modified low density lipoproteins: a potential role in recruitment and retention of monocyte/macrophages during atherogenesis. Proc. Natl. Acad. Sci. USA. 84:2995-2998.

55. Hessler, J. R., A. L. Robertson, Jr., and G. M. Chisolm. 1979. LDL-induced cytotoxicity and its inhibition by HDL in human vascular smooth muscle and endothelial cells in culture. Atherosclerosis. 32:213-229.

56. Berliner, J. A., M. C. Territo, A. Sevanian, S. Ramin, J. A. Kim, B. Bamshad, M. Esterson, and A. M. Fogelman. 1990. Minimally modified low density lipoprotein stimulates monocyte endothelial interactions. J. Clin. Invest. 85:1260-1266.

57. Kugiyama, K., S. A. Kerns, J. D. Morrisett, R. Roberts, and P. D. Henry. 1990. Impairment of endothelium-dependent arterial relaxation by lysolecithin in modified low-density lipoproteins. Nature (Lond.). 344:160-162. 